\title{
Relief for Hostile Work Environment Discrimination: Restoring Title VII's Remedial Powers
}

\section{Sharon T. Bradford}

In the landmark case of Meritor Savings Bank, FSB v. Vinson, ${ }^{1}$ the United States Supreme Court held that sexual harassment creating a hostile work environment is prohibited employment discrimination under title VII of the Civil Rights Act of 1964. ${ }^{2}$ The Court found that "Title VII is not limited to 'economic' or 'tangible' discrimination,"3 and held that the intangible harms caused by harassment are sufficient to create a title VII violation. Perhaps more importantly, the Court explicitly embraced the lower Federal courts' development of the abusive or hostile work environment cause of action in title VII cases involving racial, national origin, and religious discrimination. ${ }^{4}$

In its June, 1989 opinion in Patterson v. McLean Credit Union, ${ }^{5}$ the Supreme Court again approved the hostile work environment cause of action under title VII, and noted that title VII is the only Federal statutory protection against such discrimination. ${ }^{6}$ Yet, while courts now recognize the imperative of title VII liability for the intangible harms of employment discrimination, ${ }^{7}$ their narrow construction of title VII's relief provisions seriously undermines these findings. Courts have interpreted the statute's remedial provisions to allow only equitable relief such as injunc-

\footnotetext{
1. 477 U.S. 57 (1986).

2. 42 U.S.C. $\$ \$ 2000 \mathrm{e}-2000 \mathrm{e}-17$ (1982).

3. 477 U.S. at 64.

4. Id. at $65-66$.

5. 109 S. Ct. 2363 (1989).

6. Id. at 2374, 2377. In Palterson the Court held that section 1981 of the Civil Rights Act of 1866 does not cover racial harassment in the course of employment. See infra notes 57-60 and accompanying text.

7. Courts still differ as to the precise standards for determining employer liability for hostile work environment discrimination, and much has been written on this subject. See, e.g., 1985-1986 Annual Survey of Labor Relations and Employment Discrimination Lau: Evidence Necessary to Establish a Hostile Working Environment Claim: Erebia v. Chrysler Plastic Products Corp., 28 B.C.L. REv. 146 (1986); Note, Jailhouse Rocked: The Second Circuit Confronts a Racially Hostile Work Entrironment in a Correctional Facility, 53 BRoOKLYN L. Rev. 357 (1987); Note, Employer Liability Under Title VII for Sexual Harassment After Meritor Savings Bank v. Vinson, 87 Colum. L. Rev. 1258 (1987) [hereinafter Note, Employer Liability]; Note, Sexual Harassment Clains of Abusive Wark Environment Under Tille VII, 97 HaRv. L. REv. 1449 (1984) [hereinafter Note, Abusize Work Environment]; Note, Employer Liability for Coworker Sexual Harassment Under Title VII, 13 N.Y.U. REv. L. \& Soc. Change 83 (1985) [hereinafter Note, Cou'orker Sexual Harassment].
} 
tions and reinstatement, and not compensatory or punitive damages. The only monetary relief courts award under title VII is back pay, which is considered an equitable remedy. ${ }^{8}$ The psychological and other intangible injuries that result from an abusive work environment are not compensated. This result is inconsistent with the promise of title VII.

Ironically, this imbalance between rights and remedies reached a new extreme soon after the Supreme Court in Patterson reaffirmed the critical role of title VII in redressing hostile work environment discrimination. Applying the narrow judicial construction of title VII's relief provisions, the Court of Appeals for the Seventh Circuit refused even to hold an employer liable for hostile environment sexual harassment, despite the fact that the plaintiff had proven her claim. The court concluded that "since [the plaintiff] cannot recover any award under Title VII, [the employer] must receive judgment even if there has been a violation of that statute." This outrageous result eviscerates the Meritor Court's holding that "Title VII is not limited to 'economic' or 'tangible' discrimination."10

This Note demonstrates that the abusive or hostile work environment cause of action dramatically illustrates the inadequacy of the remedies available under the current judicial interpretation of title VII. Although this Note argues that compensatory and punitive damages should be available to remedy intangible injuries in any appropriate title VII case, ${ }^{11}$ it principally examines the hostile work environment cause of action, because title VII's coverage of psychological injuries was first recognized in this context $\mathrm{t}^{12}$ and because this cause of action most clearly demonstrates the existing imbalance between rights and remedies under title VII.

Further, this Note shows that Congress did not intend to create this imbalance. Rather, the narrow judicial construction of title VII's relief provisions derives from a misreading of the legislative history, compounded by the courts' historical failure to recognize intangible injuries. By the time employer liability for the intangible harms of discrimination was established, courts considered it settled that compensatory and punitive damages were unavailable under title VII to remedy these injuries.

This Note concludes that the imbalance between rights and remedies under title VII must be cured by Congress, and that the time is ripe for congressional action. The abundance of judicial precedents narrowly con-

8. See Curtis v. Loether, 415 U.S. 189, 197 (1974).

9. Swanson v. Elmhurst Chrysler Plymouth, Inc., 882 F.2d 1235, 1240 (7th Cir. 1989), cert. denied, 110 S. Ct. 758 (1990).

10. Meritor Sav. Bank v. Vinson, 477 U.S. 57, 64 (1986).

11. Title VII cases generally fall into two categories: disparate treatment and disparate impact. Disparate treatment cases involve an employee who is treated differently from other employees based on her race, color, religion, sex, or national origin. See McDonnell Douglas Corp. v. Green, 411 U.S. 792 (1973). The latter type of cases involve facially neutral practices that have a "disparate impact" on a protected class. See Griggs v. Duke Power Co., 401 U.S. 424 (1971). The hostile work environment cause of action does not fit neatly into either category.

12. See Rogers v. EEOC, 454 F.2d 234, 238 (5th Cir. 1971), cert. denied, 406 U.S. 957 (1972). 
struing title VII's relief provisions indicates that a judicial solution is extremely unlikely. Congress must therefore restore to the statute the broad remedial powers that were originally intended, by amending title VII to provide explicitly for compensatory and punitive damages. ${ }^{13}$

\section{Rights Without Remedies}

Employment discrimination frequently causes serious psychological harm. As the Supreme Court has recognized, "[e]ven a temporary layoff may have adverse . . . psychological effects." 14 Yet under current judicial interpretations of title VII, a victim of hostile work environment discrimination may establish employer liability, and yet obtain no relief at all since the psychological and other intangible injuries that form the basis for the employer's liability receive no compensation. ${ }^{15}$ Moreover, given the lack of any sanction other than the finding of liability itself, such decisions provide little deterrence against future discriminatory harassment. Gonsequently, under title VII, many victims of hostile work environment discrimination have been granted a right without a remedy.

\section{A. Rights: The Hostile Work Environment Cause of Action}

The hostile or abusive work environment cause of action under title VII was first recognized by the Court of Appeals for the Fifth Circuit in Rogers $v . E E O C{ }^{18}$ a national origin discrimination case. The hostile work environment theory is based on the broad language of title VII, which provides that it shall be unlawful for an employer "to fail or refuse to hire or to discharge any individual, or otherwise to discriminate against any individual with respect to his compensation, terms, conditions, or privileges of employment, because of such individual's race, color, religion, sex, or national origin."17 As Judge Goldberg stated in Rogers, this section creates "an expansive concept which sweeps within its protective ambit the practice of creating a working environment heavily charged with eth-

13. The opportunity for such legislation is currently present, since Congress is now considering the Civil Rights Act of 1990 which includes a provision for compensatory and punitive damages under title VII. Ser infra notes 133-35 and accompanying text.

14. Wygant v. Jackson Bd. of Educ., 476 U.S. 267, 283 (1986) (plurality opinion).

15. At most, victims of hostile work environment discrimination receive attorneys' fees and a few dollars of nominal damages. See, e.g., Swanson v. Elmhurst Chrysler Plymouth, Inc., 882 F.2d 1235 (7th Cir. 1989) (finding sexual harassment but awarding no relief), cert. denied, $110 \mathrm{~S}$. Ct. 758 (1990); Macko v. General Motors Corp., No. 80-CV-716 (N.D.N.Y. July 8, 1988), 1988 U.S. Dist. LEXIS 6928, 1988 WL 73446 (finding sexual harassment but awarding only attorneys' fees and one dollar in nominal damages); EEOC v. Murphy Motor Freight Lines, 488 F. Supp. 381 (D. Minn. 1980) (finding intervenor was victim of racial harassment but awarding only attorneys' fees); Compston v. Borden, Inc., 424 F. Supp. 157 (S.D. Ohio 1976) (finding religious harassment but awarding only costs, attorneys' fees, and $\$ 50$ of nominal damages). Even these minimal awards are controversial. See infra note 50 .

16. 454 F.2d 234 (5th Cir. 1971), cert. denied, 406 U.S. 957 (1972).

17. 42 U.S.C. $\$ 2000 \mathrm{e}-2(\mathrm{a})$ (1982) (emphasis added). 
nic or racial discrimination." ${ }^{18}$ Following Rogers, courts have applied the hostile work environment theory in cases involving racial harassment, ${ }^{19}$ religious harassment, ${ }^{20}$ and sexual harassment. ${ }^{21}$

Under the hostile work environment cause of action, discriminatory harassment violates title VII even if the employee does not suffer any economic harm. As Rogers held, "employees' psychological as well as economic fringes are statutorily entitled to protection from employer abuse."22 As a result, an employee may suffer hostile work environment discrimination even if she was not discriminatorily denied a promotion or fired, ${ }^{23}$ and did not lose any wages or other economic job benefits. ${ }^{24}$

Rogers defined discriminatory harassment as conduct that creates an atmosphere "so heavily polluted with discrimination as to destroy completely the emotional and psychological stability of minority group workers." ${ }^{25}$ Similarly, the Equal Employment Opportunity Commission (EEOC), the Federal agency charged with enforcing title VII, ${ }^{28}$ has defined illegal harassment under the statute as actions which have the "purpose or effect of unreasonably interfering with an individual's work performance" or of "creating an intimidating, hostile, or offensive working environment." ${ }^{\prime 27}$ Courts have generally accepted both the Rogers formula and the EEOG guidelines. ${ }^{28}$ They have, however, added a requirement that to establish a hostile work atmosphere, the employee must prove that the harassment is "sufficiently severe or pervasive "to alter the conditions of [the victim's] employment." "29

18. Rogers, 454 F.2d at 238.

19. See, e.g., Firefighters Inst. for Racial Equality v. City of St. Louis, 549 F.2d 506, 514-15 (8th Cir.), cert. denied, 434 U.S. 819 (1977).

20. See, e.g., Compston v. Borden, Inc., 424 F. Supp. 157, 160-61 (S.D. Ohio 1976).

21. See, e.g., Bundy v. Jackson, 641 F.2d 934, 943-45 (D.C. Cir. 1981).

22. Rogers, 454 F.2d at 238.

23. In some abusive environment cases, although the employee was not fired, the harassment may have resulted in a "constructive discharge" which courts treat like a firing. Even when the harassment does not amount to a constructive discharge, however, the employer may still be found liable for discriminatory harassment. See, e.g., Yates v. Avco Corp., 819 F.2d 630, 638 (6th Cir. 1987) (finding no constructive discharge, but still holding employer liable for hostile environment sexual harassment).

24. See, e.g., Snell v. Suffolk County, 611 F. Supp. 521 (E.D.N.Y. 1985) (holding plaintiffs failed to establish claim of disparate treatment in job assignments, but holding employer liable for racial harassment), aff d, 782 F.2d 1094 (2d Cir. 1986).

25. Rogers, 454 F.2d at 238.

26. 42 U.S.C. $\& 2000 \mathrm{e}-5(\mathrm{a})$ (1982).

27. 29 C.F.R. $\$ 1604.11$ (a) (1989) (defining sexual harassment); 29 C.F.R. $\S 1606.8$ (b) (1989) (identical language used to define harassment on the basis of national origin).

28. See, e.g., Meritor Sav. Bank v. Vinson, 477 U.S. 57, 65-66 (1986) (accepting both definitions and finding them consistent with each other). Courts still disagree, however, over the standards for when an employer will be held liable for such discriminatory harassment. In Meritor, the Supreme Court refused to resolve this debate in the circuits, although it did reject both absolute liability and a requirement of actual knowledge. For any further guidance, the Court simply referred the lower courts to general agency principles. 477 U.S. at 69-72; see also Note, Employer Liability, supra note 7 , at $1259-65$ (discussing various liability standards adopted by courts).

29. Meritor, 477 U.S. at 67 (quoting Henson v. City of Dundee, 682 F.2d 897, 904 (11th Gir. 1982)); accord Snell v. Suffolk County, 782 F.2d 1094, 1103 (2d Cir. 1986); Gilbert v. City of Little Rock, 722 F.2d 1390, 1394 (8th Cir. 1983), cert. denied, 466 U.S. 972 (1984). 
The emotional, psychological, and physiological injuries caused by discriminatory harassment practices can be devastating. ${ }^{30}$ Victims of hostile work environment discrimination frequently suffer from psychological symptoms such as stress, nervousness, and depression, as well as physical symptoms including nausea, insomnia, headaches, and loss of appetite. ${ }^{3 x}$ Employers should be, and in most cases are, held liable under title VII for causing or permitting such harm to their employees. ${ }^{32}$ However, the deterrent and remedial effects of a finding of liability are often nonexistent due to the strict limitations on available relief.

\section{B. Remedies: The Inadequacy of Relief Under Title VII}

Under current judicial interpretations, the only remedies provided by title VII are attorneys' fees and equitable relief such as back pay, ${ }^{33}$ injunctions, and reinstatement; no compensatory or punitive damages are awarded to redress non-economic injuries. ${ }^{34}$ Several courts have noted that were they available, compensatory and punitive damages could play a vital role in remedying the harms caused by employment discrimination. ${ }^{35}$

30. The most extensive studies of these non-economic job related injuries have been conducted in the context of sexual harassment. See, e.g., C. MacKinnon, Sexual Harassment of Working Women 47-55 (1979); U.S. Merit Systems Protection Board, Sexual Harassment in the Federal Government: AN UPDATE (1988). For a thorough discussion of studies on the origins and intractability of racial harassment, see Snell v. Suffolk County, 611 F. Supp. 521, 529-31 (E.D.N.Y. 1985), affd, 782 F.2d 1094 (2d Cir. 1986).

31. See, e.g., C. MACKINNON, supra note 30, at 47-48 (78\% of sexual harassment victims in one study suffered from emotional or physical symptoms); Crull, Stress Effects of Sexual Harassment on the Job: Implications for Counseling, 52 AM. J. ORTHOPSYcHIATRY 539, 541 (1982) (90\% of sexual harassment victims in study suffered from listed psychological stress symptoms; $63 \%$ of one group and $20 \%$ of another suffered from listed physical symptoms). A study of Federal Government workers found that during the two years from 1985 to 1987, 12,641 Federal employees sought medical assistance, emotional counseling, or both as a result of sexual harassment. U.S. MERIT SySTEMS ProteCTION BOARD, supra note 30, at 41. For compelling examples, see infra notes 46-54 and accompanying text.

32. But see supra note 9 and accompanying text.

33. Sep supra note 8 and accompanying text.

34. See, e.g., Pearson v. Western Elec. Co., 542 F.2d 1150, 1152 (10th Cir. 1976); EEOC v. Detroit Edison Co., 515 F.2d 301, 308-09 (6th Cir. 1975), vacated on other grounds, 431 U.S. 951 (1977). The purpose of a compensatory damages award is to provide a monetary substitute to compensate a plaintiff for non-economic losses that may nonetheless be measured in monetary terms. $D$. Dobis, Handbook on the LAw of Remenies $\S 3.1$ (1973). Punitive damages are designed both as a punishment for, and as a deterrent to, "particularly aggravated misconduct on the part of the defendant." Id. $\$ 3.9$, at 204 . Punitive damages are also viewed as having a compensatory component, at least insofar as they compensate the plaintiff for her wounded feelings. Id. $\$ 3.9$, at 205.

35. See, e.g., Beesley v. Hartford Fire Ins. Co., 723 F. Supp. 635, 647 (N.D. Ala. 1989) (without compensatory and punitive damages "a Title VII sexual harassment claim, as a practical matter, [is] meaningless"); Macko v. General Motors Corp., No. 80-CV-716 (N.D.N.Y. July 8, 1988), 1988 U.S. Dist. LEXIS 6928, 1988 WL 73446 ("remedial shortcomings of Title VII" limited relief for sexual harassment victim to "a mere $\$ 1$ in nominal damages"); Stewart v. Thomas, 538 F. Supp. 891, 897 (D.D.C. 1982) ("To the extent that Title VII fails to capture the personal nature of the injury done to this plaintiff as an individual, the remedies provided by that statute fail to appreciate the relevant dimensions of the problem in this [sexual harassment] case."); Compston v. Borden, Inc., $424 \mathrm{~F}$. Supp. 157, 162 (S.D. Ohio 1976) ("Were compensatory damages available to a Title VII plaintiff, this Court would not hesitate to enter such an award in this [religious harassment] case . . . ."). 
The courts, however, have generally considered such damages to be legal remedies,$^{36}$ and have held that title VII provides for only equitable relief.

This judicial consensus was developed in the mid-1970's. Ten years after the passage of the Civil Rights Act of 1964, the Federal courts were split as to the availability of damages under title VII. ${ }^{37}$ Several courts had found that compensatory and punitive damages were available, ${ }^{38}$ and one court had actually awarded punitive damages to a title VII plaintiff..$^{39}$ In the spring of 1975, however, the Court of Appeals for the Sixth Circuit overturned that award in EEOC v. Detroit Edison Co. ${ }^{40}$ and became the first circuit court to hold that such damages are not available under title VII. Shortly thereafter, other circuit courts employed the same arguments to deny compensatory and punitive damages. ${ }^{41}$ Today courts simply state summarily that compensatory and punitive damages are unavailable. ${ }^{\mathbf{2 2}}$

Without compensatory and punitive damages, title VII is stripped of its power to remedy the harms of hostile work environment discrimination. As one court stated in a sexual harassment case, "[t]o the extent that Title VII fails to capture the personal nature of the injury done to th[e] plaintiff as an individual, the remedies provided by that statute fail to appreciate the relevant dimensions of the problem." ${ }^{\text {"43 }}$ Back pay, reinstatement, or any other equitable relief that courts will award today under title VII cannot compensate for psychological and emotional injuries. Although injunctions are available to prevent recurrences of abusive behavior, the employee may be in no condition to return and benefit from the improved working environment. ${ }^{44}$ Moreover, the lack of punitive damages means that there is little deterrent value to a finding of liability for a hostile work environment. ${ }^{45}$

36. D. Doвbs, supra note $34, \S \S 3.1,3.9$.

37. Comment, Implying Punitize Damages in Employment Discrimination Cases, 9 Harv. C.R.C.L. L. REv. 325,326 (1974).

38. See, e.g., Humphrey v. Southwestern Portland Cement Co., 369 F. Supp. 832 (W.D. Tex 1973) (holding compensatory damages available), rev'a' on other grounds, 488 F.2d 691 (5th Cir. 1974); Tooles v. Kellogg Co., 336 F. Supp. 14 (D. Neb. 1972) (holding punitive damages available).

39. Stamps v. Detroit Edison Co., 365 F. Supp. 87 (E.D. Mich. 1973), rev'd sub nom. EEOC v. Detroit Edison Co., 515 F.2d 301 (6th Cir. 1975), vacated on other grounds, 431 U.S. 951 (1977).

40. 515 F.2d 301 (6th Gir. 1975), vacated on other grounds, 431 U.S. 951 (1977).

41. See, e.g., Richerson v. Jones, 551 F.2d 918 (3d Cir. 1977) (denying punitive damages); Pearson v. Western Elec. Co., 542 F.2d 1150 (10th Cir. 1976) (denying both compensatory and punitive damages).

42. See, e.g., Glezos v. Amalfi Ristorante Italiano, Inc., 651 F. Supp. 1271, 1273 (D. Md. 1987); Robinson v. Gity of Lake Station, 630 F. Supp. 1052, 1064 (N.D. Ind. 1986). But see Beesley v. Hartford Fire Ins. Co., 723 F. Supp. 635, 652 (N.D. Ala. 1989) (finding "the question of entitlement to punitive damages under Title VII . . . is still open").

43. Stewart v. Thomas, 538 F. Supp. 891, 897 (D.D.C. 1982).

44. See, e.g., Hopkins v. Shoe Show of Va., Inc., 678 F. Supp. 1241, 1243 (S.D. W. Va. 1988) (victim of racial and sexual harassment rejected defendant's offer of reinstatement, saying she " "would never work for them again' "); Brooms v. Regal Tube Co., 44 Empl. Prac. Dec. (CCH) I 37,485, at 49,377 (N.D. Ill. 1987) ("reinstatement would be inappropriate" because victim of sexual harassment "suffered a phobic reaction to the company"), affd in releviant part, 881 F.2d 412 (7th Cir. 1989).

45. As one court recently stated, "allowing nothing beyond 'nominal damages' for a series of uninvited sexual assaults, even without any accompanying demotion or discharge, would render a 
Several cases clearly illustrate the results of this imbalance between rights and remedies. ${ }^{18}$ For example, in Compston v. Borden, Inc., ${ }^{47}$ a religious harassment case, the court found that the plaintiff had been the victim of "numerous derogatory epithets and . . . a patterned course of conduct designed to make his working environment a miserable one," but that he had not suffered any economic harm. ${ }^{48}$ The court noted that "[w]ere compensatory damages available to a Title VII plaintiff, this Court would not hesitate to enter such an award in this case, because it is apparent from the evidence that Compston suffered mental anguish and humiliation at defendants' hands." ${ }^{\text {"9 }}$ In an effort to give some minimal relief, the court awarded nominal damages of fifty dollars. ${ }^{50}$

Similarly, in the sexual harassment case of Zabkowicz v. West Bend $\mathrm{Co}_{0},{ }^{\mathrm{s} 1}$ the court found that the plaintiff had been subjected to four years of "sustained, malicious, and brutal harassment" that was "more than merely unreasonable; it was malevolent and outrageous." 22 Indeed, four years of egregious verbal abuse, offensive physical gestures, and demeaning sexually oriented drawings of herself had caused Mrs. Zabkowicz to suffer from "diarrhea, vomiting, severe nausea, and cramping," which was diagnosed as " "psychophysiological gastro-intestinal disease due to harassment at work.'" 53 The only economic injury to Mrs. Zabkowicz, however, was the loss of two months' pay due to a medical leave of absence her illness had required her to take. As a result, the only remedy awarded was two months of back pay. ${ }^{54}$

\section{The Inadequacy and Impropriety of Alternative Remedies}

Given the lack of damages remedies under title VII, many victims of discriminatory harassment have turned to other potential sources of relief. Although in some cases these alternative approaches have been successful, they are of limited and diminishing availability. Until recently, victims of racial harassment were often able to obtain compensatory and punitive damages by appending a claim under section 1981 of the Civil Rights Act

Title VII sexual harassment claim, as a practical matter, meaningless." Beesley, 723 F. Supp. at 647.

46. Sep C. Newkirk, E. Vargyas \& M. Greenberger, Title VII's Failed Promise: The IMPACT of the LACK of a Damages Remedy 10-23 (1990) (Report by National Women's Law Center) (discussing many such cases).

47. 424 F. Supp. 157 (S.D. Ohio 1976).

48. Id. at 160 .

49 . Id, at 162 .

50. Id. Courts disagree over whether nominal damages may be awarded under title VII to create a remedy upon which to attach an award of costs and attorneys' fees. Compare Henson v. City of Dundee, 682 F.2d 897, 905-06 (11th Cir. 1982) (nominal damages may be awarded) with Bohen v. City of East Chicago, 799 F.2d 1180, 1184 (7th Cir. 1986) (nominal damages not available).

51. 589 F. Supp. 780 (E.D. Wis. 1984).

52. Id. at 784 .

53. Id. at 783 (quoting doctor's diagnosis).

54. Id. at 785. In a separate proceeding, the Seventh Circuit held that she was also entitled to attorneys' fees. Zabkowicz v. West Bend Co., 789 F.2d 540, 554 (7th Cir. 1986). 
of 1866, a Reconstruction-era statute prohibiting racial discrimination that impedes the right "to make and enforce contracts." Although the Court had held in 1976 that section 1981 applies to private conduct, ${ }^{56}$ the Supreme Court's recent decision in Patterson v. McLean Credit Union ${ }^{57}$ foreclosed this avenue of relief. In Patterson, the Court construed section 1981 extremely narrowly and held that claims of racial harassment are not actionable under this statute. ${ }^{58}$ The impact of the Patterson decision has been dramatic; during the first four and one-half months after the opinion was issued twenty-two racial harassment cases were dismissed. ${ }^{58}$ Ironically, the Patterson Court relied on the availability of title VII remedies in holding that section 1981 does not cover racial harassment. ${ }^{60}$

The alternative sources for relief in sexual harassment cases are also problematic. Some sexual harassment victims have recovered compensatory damages under state civil rights statutes, ${ }^{61}$ or through an equal protection claim under section 1983 of the Civil Rights Act of $1871{ }^{62}$ But few states have enacted statutes banning sexual harassment, and section 1983 applies only to state employers. ${ }^{63}$ In addition, section 1983 requires proof of discriminatory intent, ${ }^{64}$ and thereby prohibits holding the employer vicariously liable for sexual harassment by a co-worker ${ }^{85}$

In general, victims of sexual harassment must rely on a variety of inadequate tort remedies to obtain any compensation for their psychological and other intangible injuries. ${ }^{68}$ The tort theories used by such plaintiffs include assault and battery, intentional infliction of emotional distress, in-

55. 42 U.S.C. $§ 1981$ (1982); see, e.g., Hunter v. Allis-Chalmers Corp., 797 F.2d 1417 (7th Cir. 1986) (upholding award of $\$ 25,000$ compensatory damages and $\$ 25,000$ punitive damages for racial harassment under section 1981); Erebia v. Chrysler Plastic Products Corp., 772 F.2d 1250 (6th Cir. 1985) (upholding award of $\$ 30,000$ punitive damages under section 1981 for racial harassment), cert. denied, 475 U.S. 1015 (1986).

56. Runyon v. McCrary, 427 U.S. 160 (1976).

57. 109 S. Ct. 2363 (1989).

58. Id. at 2374 .

59. Marcus, Ruling Said to Spur Dismissal of Bias Suits, Washington Post, Nov. 20, 1989, at A6, col. 3 .

60. 109 S. Ct. at 2375 ("That egregious racial harassment of employees is forbidden by a clearly applicable law (Title VII), moreover, should lessen the temptation for this Court to twist the interpretation of another statute ( $\$ 1981)$ to cover the same conduct.").

61. See, e.g., Coley v. Consolidated Rail Corp., 561 F. Supp. 645 (E.D. Mich. 1982) (awarding sexual harassment victim $\$ 5,000$ damages for mental anguish and humiliation under Michigan's Elliott-Larsen Civil Rights Act); see also Note, Legal Remedies for Employment-Related Sexual Harassment, 64 MinN. L. REv. 151 (1979) (proposing model state statute prohibiting sexual harassment).

62. 42 U.S.C. $\$ 1983$ (1982); see, e.g., Bohen v. City of East Chicago, 666 F. Supp. 154 (N.D. Ind. 1987) (awarding sexual harassment victim $\$ 25,000$ for mental distress and $\$ 4,150$ for medical expenses under section 1983 claim), enforcing 799 F.2d 1180 (7th Cir. 1986) (holding equal protection claim for sexual harassment actionable under section 1983).

63. See Bohen v. City of East Chicago, 799 F.2d 1180, 1185 (7th Cir. 1986).

64. Id. at 1186.

65. Dworkin, Ginger \& Mallor, Theories of Recowery for Sexual Harassment: Going Beyand Tille VII, 25 SAN DiEgo L. REv. 125, 135-36 (1988).

66. See Comment, $A$ Theory of Tort Liability for Sexual Harassment in the Workplace, $134 \mathrm{U}$. PA. L. REv. 1461 (1986) (arguing that traditional tort theories are inadequate and proposing new tort cause of action). 
vasion of privacy, and intentional interference with contract. ${ }^{67}$ These causes of action, however, vary widely from state to state and "[n]o single rubric provides adequate relief." ery is the tort doctrine of respondeat superior, under which an employer may be held vicariously liable for the torts of her employees only when the torts are committed in furtherance of their employment. This doctrine has often been used to deny relief for discriminatory harassment by coworkers, and to limit tort recovery to situations in which the employer has authorized the discriminatory mistreatment. ${ }^{60}$

Not only are these alternative causes of action wholly inadequate in providing uniform, reliable, or adequate relief, but more importantly, alternative paths should not be necessary to provide complete relief to victims of employment discrimination. Congress intended that title VII serve as a comprehensive Federal tool to "eliminate, through the utilization of formal and informal remedial procedures, discrimination in employment." 70 Thus, the need to resort to external causes of action contravenes the spirit and goals of title VII.

\section{The Derivation of the Imbalance}

The legislative history of title VII's relief provisions, although limited, indicates that Congress intended to provide courts with broad discretion to award any type of remedy that is appropriate in a given case. Consequently, amending title VII to provide explicitly for compensatory and punitive damages, would, by invalidating the courts' unduly narrow reading of title VII, restore the statute to its originally intended role. ${ }^{71}$

The courts' refusal to adopt a broad approach to remedies under title VII $^{72}$ essentially stems from two sources. First, the courts improperly con-

67. See Dworkin, Ginger \& Mallor, supra note 65, at 137-46 (describing these tort causes of action for sexual harassment).

68. Comment, supra note 66, at 1484-85. For example, although the Washington, D.C. courts have broadly defined the tort of intentional infliction of emotional distress to include some cases of hostile environment sexual harassment, the standard is significantly more demanding than that under title VII. See Howard Univ. v. Best, 484 A.2d 958, 986 (D.C. 1984) (holding sexual harassment constitutes intentional infliction of emotional distress only if conduct was "so outrageous in character, and so extreme in degree, as to go beyond all possible bounds of decency" "(citation omitted)).

69. See Note, Abusize Work Environment, supra note 7, at 1464 . Vicarious liability is absolutely necessary to remove harassment from the workplace. Only the employer has sufficient control to alter the work atmosphere by, for example, disciplining employees who create a discriminatory work environment. See generally Note, Coworker Sexual Harassment, supra note 7 (arguing employers should be vicariously liable for sexual harassment of their employees by coworkers).

70. H.R. Rep. No. 914, 88th Cong., 2d Sess., reprinted in 1964 U.S. Code Cong. \& ADMIN. NEws 2391, 2401. The development of a variety of state law and other external causes of action further erodes the effectiveness of title VII as a comprehensive Federal anti-discrimination weapon.

71. The "restoration" concept was the theory behind the Civil Rights Restoration Act, Pub. L. No. 100-259, 102 Stat. 28 (1988). That act overturned the Supreme Court's decision in Grove City College v. Bell, 465 U.S. 555 (1984), which had construed too narrowly the scope of the protections against sex discrimination provided by title IX of the Education Amendments of 1972, Pub. L. No. 92-318, 86 Stat. 235, 373.

72. See supra notes $37-42$ and accompanying text. 
strued title VII's legislative history. Second, the courts' interpretation of title VII was formed prior to their recognition of the hostile work environment cause of action and the appropriateness of compensatory and punitive damages under title VII.

\section{A. Improper Statutory Interpretation}

In 1972, Congress passed the Equal Employment Opportunity Act $^{73}$ to amend various provisions of title VII, including section $706(\mathrm{~g})$, which delineates the relief available under the Act. The legislative history surrounding the amendment of section $706(\mathrm{~g})$ is extremely limited, and there is no evidence in the Act, the amendments, or the legislative history that Congress ever explicitly considered whether compensatory or punitive damages should be awarded under title VII. ${ }^{74}$ Nonetheless, a proper reading of title VII and its legislative history demonstrates that the statute's relief provisions should be construed broadly. Under well established principles of statutory construction, courts must look first to the language of a statute, ${ }^{75}$ and the language of section $706(\mathrm{~g})$ is expansive. ${ }^{76}$ Moreover, compensatory and punitive damages have been awarded under several statutes that do not explicitly provide for such relief. ${ }^{77}$ As one commentator has argued, " $t$ ]here is nothing new ... in federal courts' implying the availability of remedies that are not explicitly provided by a particular statute. The theory is that 'the existence of a statutory right implies the existence of all necessary and appropriate remedies." "'r8 This policy is especially sound where the additional remedy is needed to fulfill the purpose of the statute. ${ }^{79}$ This rationale clearly applies in the context of title VII.

The courts, however, have misread the statutory language of section $706(\mathrm{~g})$ and have consequently refused to infer the existence of compensatory and punitive damages under title VII. The case that was most influential in establishing this narrow judicial interpretation of title VII was Van Hoomissen v. Xerox Corp. ${ }^{80}$ an opinion by the United States District Court for the Northern District of Galifornia. The Van Hoomissen opinion provided arguments that were employed as each circuit in turn

73. Pub. L. No. 92-261, 86 Stat. 103 (1972).

74. See Richards, Compensatory and Punitive Damages in Employment Discrimination Cases, 27 ARK. L. REv. 603, 618 (1973).

75. See Consumer Prod. Safety Comm'n v. GTE Sylvania, Inc., 447 U.S. 102, 108 (1980); Tello v. McMahon, 677 F. Supp. 1436, 1441 (E.D. Cal. 1938).

76. See infra notes $84-90$ and accompanying text.

77. These statutes include section 1983 of the Civil Rights Act of 1871, 42 U.S.C. $\$ 1983$ (1982), and section 404(b) of the Federal Aviation Act of 1958, 49 U.S.C. $\$ 1374$ (b) (1982). Sep Comment, supra note 37 , at 332-33.

78. Comment, supra note 37 , at 331 (quoting Sullivan v. Little Hunting Park, Inc., 396 U.S. 229,239 (1969)).

79. See id. at 333.

80. 368 F. Supp. 829 (N.D. Cal. 1973). 
denied the availability of compensatory and punitive damages under title VII. ${ }^{81}$ The Van Hoomissen court arrived at its decision through statutory construction, an examination of the legislative history, and a comparison of title VII with two other statutes. None of the court's rationales is persuasive; in fact, each is fundamentally flawed. ${ }^{\mathbf{2 2}}$

\section{Statutory Construction}

The Van Hoomissen court's weakest rationale for its decision stems from its statutory construction of section 706(g). The Van Hoomissen court stated that a court may infer the availability of damages when a statute "speaks only in the most general of remedial terms," but when several specific remedies are listed, no such inference may be drawn. ${ }^{83}$ However, the court's conclusion that Congress intended to restrict the types of remedies available under title VII to those specifically listed in section $706(\mathrm{~g})$ belies the statutory language Congress chose to employ.

Congress provided in section $706(\mathrm{~g})$ that courts may "enjoin the . . . unlawful employment practice, and order such affirmative action as may be appropriate." ${ }^{84}$ The language "such affirmative action as may be appropriate" confers great flexibility on the courts and could easily be interpreted to encompass both legal and equitable relief. ${ }^{85}$ The remaining language of section $706(\mathrm{~g})$ further indicates that Congress intended to provide complete relief under title VII. In amending the statute in 1972, Congress added two phrases to section 706(g)'s list of specifically authorized remedies: "but is not limited to" at the beginning of the list and "or any other equitable relief as the court deems appropriate" at the end. The resulting section authorizes courts to "order such affirmative action as may be appropriate, which may include, but is not limited to, reinstatement or hiring of employees, with or without back pay . . . or any other equitable relief as the court deems appropriate." 86 As courts have noted, the latter phrase indicates that the specifically listed remedies of "reinstatement or

81. See, e.g., Harrington v. Vandalia-Butler Bd. of Educ., 585 F.2d 192, 194-97 (6th Cir. 1978) (holding compensatory damages unavailable), cert. denied, 441 U.S. 932 (1979); Richerson v. Jones, 551 F.2d 918, 926-28 (3d Cir. 1977) (denying availability of punitive damages); Pearson v. Western Elec. Co., 542 F.2d 1150, 1151-52 (10th Cir. 1976) (denying both compensatory and punitive damages); Whitney v. Greater N.Y. Corp. of Seventh-Day Adventists, 401 F. Supp. 1363, 1368-71 (S.D.N.Y. 1975) (same).

82. For an early critique of the Van Hoomissen court's analysis, which forms the groundwork for several of the arguments that follow, see Comment, supra note 37, at 337-45.

83. Van Hoomissen, 368 F. Supp. at 838 .

84. 42 U.S.C. \$2000e-5(g) (1982).

85. Moreover, Congress had not employed this specific phrase in any prior statute. Thus, not only does the actual statutory language resoundingly invite a broad construction, but the courts were completetly free from potentially constraining precedent. The closest language is that of the National Labor Relations Act (NLRA), which authorizes "such affirmative action . . . as will effectuate the policies of this subchapter." 29 U.S.C. $\$ 160$ (c) (1982). This language is more constraining than title VII's open-ended phrase "as may be appropriate." For a further discussion of the NLRA comparison, see infra notes 96-109 and accompanying text.

86. 42 U.S.C. $\S 2000 \mathrm{e}-5(\mathrm{~g})(1982)$ (italics indicate language added by 1972 amendments). 
hiring of employees, with or without back pay" are considered to be equitable relief, and that courts could use wide discretion in fashioning other equitable remedies. ${ }^{87}$ Commentators have long recognized that remedies beyond equitable relief may be available since the first phrase, "but is not limited to," is an expansive one. ${ }^{\mathbf{8 8}}$

The 1972 amendments, however, support an even stronger claim. More specifically, had Congress only intended to broaden the equitable relief available under title VII, it would have been sufficient to add the "or any other equitable relief" clause at the end of section 706(g)'s list of remedies. Instead, Congress simultaneously added the phrase "but is not limited to" as part of the 1972 amendments. Despite the significance of this phrase, the courts' current construction of section $706(\mathrm{~g})$ renders it a nullity, thereby violating fundamental principles of statutory construction. ${ }^{89}$ The phrase "but is not limited to" modifies the entire list of specified remedies, including the term "any other equitable relief." Consequently, if the relief is "not limited to" the whole range of available equitable remedies, section $706(\mathrm{~g})$ must also permit awards of legal relief such as compensatory and punitive damages. Had the Van Hoomissen court analyzed the "but is not limited to" clause, it should have concluded that Congress, unwilling and unable to predict the full extent of "appropriate" relief under title VII, deliberately left open the possibility of legal relief under title VII. The court's error has been perpetuated as courts following Van Hoomissen have also ignored this critical phrase. ${ }^{90}$

\section{Legislative History}

The Van Hoomissen court's analysis of title VII's legislative history is similarly flawed. The court focused on outdated legislative history from section 706(g)'s original enactment in 1964 and irrelevant legislative history regarding the 1972 amendments to other provisions of title VII. ${ }^{91} \mathrm{As}$ the court correctly noted, however, the legislative history of the current version of section $706(\mathrm{~g})$ itself is quite limited. ${ }^{92}$ Indeed, the Joint Explanatory Statement of Managers included in the Conference Report for the 1972 amendments simply indicates that the Senate accepted the House version of section $706(\mathrm{~g}) . .^{93}$

87. See, e.g., EEOG v. Detroit Edison Co., 515 F.2d 301, 309 (6th Cir. 1975), zracated on other grounds, 431 U.S. 951 (1977).

88. See, e.g., Comment, supra note 37, at 337; Note, Coworker Sexual Harassment, supra note 7 , at 111.

89. See, e.g., Reiter v. Sonotone Corp., 442 U.S. 330, 339 (1979) (holding that "in construing a statute [courts] are obliged to give effect, if possible, to every word Congress used").

90. See, e.g., Richerson v. Jones, 551 F.2d 918, 928 (3d Cir. 1977) (asserting that in 1972 "Congress merely added a provision which permitted courts to award any other equitable relief as the court deems appropriate.'").

91. Van Hoomissen v. Xerox Corp., 368 F. Supp. 829, 836-37 (N.D. Cal. 1973).

92. Id. at 836 .

93. H.R. Conf. Rep. No. 899, 92d Cong., 2d Sess., reprinted in 1972 U.S. Cone Cong. \& 
Although the Van Hoomissen court did quote one of the few paragraphs on section $706(\mathrm{~g})$ from the 1972 debates, ${ }^{94}$ it failed to explain how it concluded from this brief passage that Congress intended to deny compensatory and punitive damages to title VII plaintiffs. ${ }^{95}$ The quoted language is extremely broad and vague, and neither it nor anything else in the legislative history indicates that Congress intended to circumscribe in any way the types of relief available under title VII.

\section{Comparisons with Other Statutes}

The Van Hoomissen court also attempted to bolster its interpretation of title VII's relief provisions through comparisons with those of the National Labor Relations Act (NLRA) ${ }^{86}$ and the Fair Housing Act, ${ }^{97}$ but these arguments are also weak. Under the NLRA rationale, the court pointed out that the relief provisions of title VII were modeled on those of the NLRA, which had already been held not to provide for compensatory or punitive damages. ${ }^{98}$ The relief provisions of title VII, however, were never identical to those of the NLRA and were significantly broadened in $1972 .{ }^{99}$ Indeed, Congress' insertion of the phrase "but is not limited to" before the list of specific remedies authorized under title VII suggests that Congress specifically intended to enlarge title VII relief beyond that provided under the NLRA.

In addition, despite the remaining similarity in language between the relief provisions of title VII and the NLRA, the remedial goals of the two statutes are fundamentally different. ${ }^{100}$ Whereas the NLRA seeks to pro-

ADMIN. News 2137, 2179, 2183.

94. Van Hoomissen, 368 F. Supp. at 837 . The language, however, does not appear on the cited page of the Congressional Record. It seems to have been taken from a section-by-section analysis of the bill prepared by two Senators. See 118 Cong. REc. 7166, 7168 (daily ed. March 6, 1972).

95. After quoting the language, the court first noted that its ambiguity "has been a source of confusion among the district courts," and in its next sentence asserted that "the general legislative history .... indicates that the remedies intended were those [specifically] provided for" in section 706(g). Van Hoomissen, 368 F. Supp. at 837.

96. 29 U.S.C. $\$ 160($ b) - (c) (1982).

97. 42 U.S.C.A. § 3613(c) (West Supp. 1989).

98. Van Hoomissen, 368 F. Supp. at 837. See, e.g., Consolidated Edison Co. v. NLRB, 305 U.S. 197, 235-36 (1938) (no punitive damages under NLRA).

99. See supra note 85. Compare section 10(c) of the NLRA, 29 U.S.C. $§ 160($ c) (1982) with section 706(g) of title VII, 42 U.S.C. $\$ 2000 \mathrm{e}-5(\mathrm{~g})$ (1982).

100. Moreover, the NLRA comparision is inapposite because the NLRA and title VII differ substantially in their enforcement mechanisms. See Comment, supra note 37, at 342-43. Under the NLRA, relief is provided by an administrative agency, the National Labor Relations Board, 29 U.S.C. $\$ 160$ (a)-(c) (1982), a fact that influenced the Supreme Court's holding that no punitive damages are available under the NLRA. See Republic Steel Corp. v. NLRB, 311 U.S. 7, 11 (1940) (finding that Congress could not have "intended to vest in the Board a virtually unlimited discretion to devise punitive measures"). Under title VII, by contrast, even though cases are initially reviewed by an administrative agency, the EEOC, it is only authorized to attempt a resolution through "informal methods of conference, conciliation, and persuasion." 42 U.S.C. $\$ 2000 \mathrm{e}-5(\mathrm{~b})$ (1982). Relief under title VII is provided by the courts, 42 U.S.C. $\S 2000 \mathrm{e}-5(\mathrm{~g})(1982)$, which are clearly capable of awarding damages. 
mote industrial peace ${ }^{\mathbf{1 0 1}}$ and is designed essentially as a group remedy, ${ }^{\mathbf{1 0 2}}$ title VII strives to end all employment discrimination and to relieve the injuries of individual victims. ${ }^{103}$ For example, under the NLRA, discriminatory discharges of active union members violate the Act not because of their adverse effects on the fired employees, but because the discharges chill the unionism of the remaining employees. ${ }^{104}$ Consequently, the victims of the discharge are the remaining workers, and the remedy of reinstatement is implemented primarily as a means to protect their rights of self-organization, and only secondarily as a method of compensating those who were actually fired. ${ }^{105}$ Compensatory damages are therefore unnecessary, since the remaining employees will not generally have suffered the type or degree of intangible injuries that such damages are designed to redress. Punitive damages are also inappropriate, since they would counter the statutory goal of promoting industrial peace. ${ }^{106}$

Title VII, by contrast, concerns itself with the fired employees, and "the basic policy of the statute requires that [courts] focus on fairness to individuals rather than fairness to classes." 107 Although an employer's discriminatory practices may affect employees on a classwide basis, title VII remedies are designed "to make persons whole for injuries suffered on account of unlawful employment discrimination." ${ }^{\text {"108 }}$ Therefore, the remedial goals of title VII would be furthered by compensatory damages to redress individuals' intangible injuries. Furthermore, unlike the NLRA's overarching goal of promoting industrial peace, "the primary objective [of title VII i]s a prophylactic one," ${ }^{109}$ and punitive damages would further this objective by deterring future discrimination.

The Van Hoomissen court also compared title VII to the Fair Housing Act of title VIII of the Givil Rights Act of 1968, which specifically provides for punitive damages. ${ }^{110}$ The court concluded that had Congress in-

101. NLRB v. American Nat'l Ins. Co., 343 U.S. 395, 401-02 (1952).

102. Local Union No. 12, Progressive Mine Workers v. NLRB, 189 F.2d 1, 5 (7th Cir.), cert denied, 342 U.S. 868 (1951).

103. Between the original drafting of section $706(\mathrm{~g})$ and the ultimate enactment of title VII in 1964, Congress shifted its theory of title VII from a "public right" to a "private right" of action. Sef Comment, Enforcement of Fair Employment Under the Civil Rights Act of 1964, 32 U. CHI. L. REv. 430,466 (1965). Consequently, title VII was enacted in 1964 as a private rights statute with only the language of a public rights statute.

104. See Textile Workers Union v. Darlington Mfg. Co., 380 U.S. 263, 275-76 (1965).

105. For example, under the Supreme Court's approach in Darlington, the victims of a discriminatory plant closing were not the union members who had lost their jobs, but the employees at the remaining plants who would perceive the closing as a threat. Id.

106. See Claiborne v. Illinois Cent. R.R., 401 F. Supp. 1022, 1024-25 (E.D. La. 1975) (arguing that while the NLRA would be undermined by punitive damages, title VII would not be), modified, 583 F.2d 143 (5th Cir. 1978), cert. denied, 442 U.S. 934 (1979).

107. Los Angeles Dept. of Water \& Power v. Manhart, 435 U.S. 702, 709 (1978).

108. Albemarle Paper Co. v. Moody, 422 U.S. 405, 418 (1975).

109. Id. at 417 .

110. 42 U.S.C.A. $\$ 3613$ (c) (West Supp. 1989). The provision analyzed by the Var Hoomissen court provided that courts could award "actual damages and not more than $\$ 1000$ punitive damages." 42 U.S.C. $\$ 3612$ (c) (1982). This was the original relief provision. Congress only recently removed 
tended to allow such damages under title VII, it would have drafted similarly explicit language. However, the fact that Congress did not add a similar provision to title VII when amending that statute in 1972 tells us very little. As one commentator has pointed out, the Van Hoomissen court based its argument that the comparison to the Fair Housing Act was "illuminating"111 on a mistaken notion: that the Fair Housing Act was passed as part of an amendment to the Civil Rights Act of 1964, so that the Fair Housing Act and title VII had become part of the same Act. ${ }^{112}$

Significantly, in EEOC v. Detroit Edison Co., ${ }^{113}$ the first circuit court to hold that punitive damages are unavailable under title VII made the same error. It stated that the Fair Housing Act was "Title VIII of the Civil Rights Act of 1964 [which] was amended in 1968" to provide for punitive damages, and concluded that since Congress had "set forth with such particularity the remedies permitted under the portion of the Civil Rights Act relating to discrimination in housing," the lack of such a provision in title VII was significant. ${ }^{114}$ However, although the Fair Housing Act is also called "title VIII," it is title VIII of the Civil Rights Act of 1968, not the next title sequentially after title VII in the 1964 Act. ${ }^{115}$ Indeed, Congress never considered these two statutes together, since it passed the Fair Housing Act four years after the enactment of title VII and four years before title VII was amended. ${ }^{116}$ As other courts followed Van Hoomissen and Detroit Edison in holding that punitive and compen-

this cap on damages as part of the Fair Housing Amendments Act of 1988, Pub. L. No. 100-430, 102 Stat. 1619, 1633. The Act now provides simply that "the court may award to the plaintiff actual and punitive damages." 42 U.S.C.A. \& 3613(c) (West Supp. 1989).

111. Van Hoomtsien, 368 F. Supp. at 837.

112. Comment, supra note 37 , at 339 . The author notes that in the original published version of the opinion, the court actually referred to the two statutes as "part of the same 1964 Civil Rights Act." This phrase was removed from the version currently printed in the Federal Supplement. Id.

113. 515 F.2d 301 (6th Cir. 1975), vacated on other grounds, 431 U.S. 951 (1977).

114. Id. at 309 .

115. The actual title VIII of the Civil Rights Act of 1964 is entitled "Registration and Voting Statistics" and provides that voting statistics shall be compiled by race and national origin to ensure that registered voters do indeed vote. Civil Rights Act of 1964, Pub. L. No. 88-352, 78 Stat. 241, 266.

116. One might argue that title VII and the Fair Housing Act are nonetheless both antidiscrimination statutes with similar structures, and therefore it is still instructive to compare the affirmative mention of punitive damages in the Fair Housing Act with the absence of such a term in title VII. However, the lesson one may learn from this comparison is that punitive damages were presumptively available under both statutes, and the specific provision in the Fair Housing Act was intended to drlimit an otherwise unfettered right to such damages. The provision of the Fair Housing Act to which the Van Hoomissen court referred was the original relief section, see supra note 110 , which provided that a "court may grant as relief, as it deems appropriate . . . actual damages and not more than \$1000 punitive damages." 42 U.S.C. $\$ 3612$ (c) (1982) (emphasis added). In construing this language, at least one Federal court of appeals held that under the Fair Housing Act "[t]he statutory provisions relating to punitive damages do not create a new right and are designed to limit the amount of recovery to $\$ 1,000$ where punitive damages are found to be appropriate.": Steele v. Title Realty Co., 478 F.2d 380, 384 (10th Cir. 1973) (emphasis added); see also Richards, supra note 74, at 618. Under this interpretation, Congress, by its failure to adopt a similar provision in title VII, left the availability of damages intact; no affirmative mention of such damages was necessary. 
satory damages are unavailable under title VII, they repeated the Fair Housing Act argument without detecting this critical error. ${ }^{117}$

Despite the weaknesses of the Van Hoomissen court's analysis, courts have continued to rely on its arguments and to follow its holding. Indeed, since the Sixth Circuit overturned the Detroit Edison district court's award of punitive damages, ${ }^{118}$ no award of compensatory or punitive damages under title VII has withstood an appeal. ${ }^{119}$

\section{B. Timing}

In addition to relying on improper statutory interpretation, courts have limited title VII remedies because their construction of the statute's relief provisions was fixed before they recognized the need for and "appropriateness" of compensatory and punitive damages under title VII. During the early 1970's, the Rogers $v$. EEOC court was the only circuit court to recognize the hostile work environment theory and hold that "employees' psychological as well as economic fringes are statutorily entitled to protection from employer abuse."120 Indeed, four years after the Fifth Circuit's decision in Rogers, the Supreme Court still maintained the narrow view that "Title VII deals with legal injuries of an economic character."121 Moreover, courts did not yet understand the subtle and pervasive character of employment discrimination and the consequent need for the deterrent of punitive damages.

Even several years after Rogers, most courts incorrectly believed that title VII only covered tangible, economic harms. This pervasive view was well captured in a law review article widely cited during this time, which stated that under title VII, "[e]ssentially the only uncompensated elements of damage, therefore, are the psychological injuries-for instance, humiliation and mental suffering. To go so far as to imply a compensatory damage remedy solely for this type of injury would be of doubtful propriety ...."122 This common misperception was not corrected until after the law had become settled that compensatory and punitive damages were un-

117. See, e.g., Richerson v. Jones, 551 F.2d 918, 927-28 (3d Gir. 1977) (denying punitive damages); Pearson v. Western Elec. Co., 542 F.2d 1150, 1152 (10th Cir. 1976) (denying both compensatory and punitive damages); Whitney v. Greater N.Y. Corp. of Seventh-Day Adventists, 401 F. Supp. 1363, 1370 (S.D.N.Y. 1975) (same).

118. Stamps v. Detroit Edison, 365 F. Supp. 87 (E.D. Mich. 1973), rev'd sub nom. EEOC v. Detroit Edison Co., 515 F.2d 301 (6th Cir. 1975), wacated on other grounds, 431 U.S. 951 (1977); see supra text accompanying notes $39-40$.

119. The district court's award of $\$ 50,000$ in punitive damages under title VII and section 1981 in Claiborne v. Illinois Cent. R.R., 401 F. Supp. 1022 (E.D. La. 1975), was upheld on appeal but only on the section 1981 grounds. 583 F.2d 143 (5th Gir. 1978), cert denied, 442 U.S. 934 (1979).

120. Rogers v. EEOC, 454 F.2d 234, 238 (5th Cir. 1971), cert. denied, 406 U.S. 957 (1972).

121. Albemarle Paper Co. v. Moody, 422 U.S. 405, 418 (1975) (emphasis added).

122. Developments in the Law: Employment Discrimination and Tille VII of the Civil Rights Act of 1964, 84 HARv. L. REv. 1109, 1260 (1971) [hereinafter Decelopinents]. At least one court actually relied on this article as authority for denying damages. See Whitney v. Greater N.Y. Corp. of Seventh-Day Adventists, 401 F. Supp. 1363, 1370 (S.D.N.Y. 1975). 
available under title VII. The first cases to follow Rogers in adopting the hostile work environment theory were decided in $1976,{ }^{123}$ one year after the landmark court of appeals decision in Detroit Edison. ${ }^{\mathbf{1 2 4}}$ Consequently, only one circuit court initially confronted the title VII damages issue in the context of a hostile environment cause of action. ${ }^{125}$ Interestingly, the Fifth Circuit, which in Rogers was the first to recognize the hostile work environment theory, was the most reluctant to hold that title VII does not permit damages awards. ${ }^{126}$

Moreover, the majority of the early hostile work environment cases involved race discrimination, ${ }^{\mathbf{1 2 7}}$ and prior to the Supreme Court's recent decision in Patterson v. McLean Credit Union, ${ }^{128}$ section 1981 was available as an alternative source of compensatory and punitive damages for racial harassment. ${ }^{129}$ Consequently, these earlier cases put little pressure on courts to reconsider the availability of such damages under title VII. Indeed, the Court of Appeals for the Ninth Circuit appears to have relied on the availability of section 1981 as an alternative source of relief when it first held that compensatory and punitive damages were not available under title VII. ${ }^{130}$ The sexual harassment abusive work environment cause of action, which has more clearly posed the problem of a right without a remedy, was not recognized until 1981 in Bundy v. Jackson. ${ }^{\mathbf{1 3 1}}$

This gap in timing also demonstrates that Congress' failure to amend title VII to overturn the courts' wrongfully narrow construction of the statute was not necessarily due to congressional acquiescence. Rather, the fact that the courts' interpretation of title VII's relief provisions was not in conformity with Congress' intent has only recently become apparent. The failure of the courts to implement the congressional mandate to provide all "appropriate" relief was not easy to detect as long as title VII plaintiffs

123. St', e.g., Gray v. Greyhound Lines, 545 F.2d 169 (D.C. Cir. 1976).

124. EEOG v. Detroit Edison Co., 515 F.2d 301 (6th Cir. 1975), vacated on other grounds, 431 U.S. 951 (1977). See supra text accompanying notes 37-42.

125. This court was the newly created Eleventh Circuit. By the time it did so, however, virtually every other circuit had already confronted the issue and decided that compensatory and punitive damages were unavailable under title VII. The Eleventh Circuit felt compelled to do the same. See Walker v. Ford Motor Co., 684 F.2d 1355, 1363-64 (11th Cir. 1982).

126. In the race discrimination case of Claiborne v. Illinois Cent. R.R., 401 F. Supp. 1022 (E.D. La. 1975), morlified, 583 F.2d 143 (5th Gir. 1978), cert. denied, 442 U.S. 934 (1979), the lower court had awarded punitive damages under both title VII and section 1981. The Fifth Circuit affirmed the award only on the section 1981 grounds, but did so "[w]ithout approving or disapproving the lower court's resolution of the Title VII issue [because] its discussion of Title VII . . . is fully persuasive that an award of punitive damages does not so conflict with the purpose embodied in Title VII . . .." 583 F.2d at 154.

127. Ser, e.g., Firefighters Inst. for Racial Equality v. City of St. Louis, 549 F.2d 506, 514-15 (8th Cir.), cert. denied, 434 U.S. 819 (1977).

128. 109 S. Ct. 2363 (1989).

129. See supra notes 55-58 and accompanying text.

130. Ste Shah v. Mt. Zion Hosp. \& Medical Center, 642 F.2d 268 (9th Gir. 1981). After devoting little analysis to the title VII issue, the Shah court noted that "[i]n an appropriate case, compensatory and punitive damages may be available under 42 U.S.C. \$ 1981." Id. at 272.

131. 641 F.2d 934, 943 (D.C. Cir. 1981) (noting case of first impression). 
were obtaining relief for their economic injuries. It was not until plaintiffs in "pure" hostile work environment cases began to obtain judgments of liability without the award of any remedies that Congress had a real opportunity to observe that title VII has been seriously misconstrued. ${ }^{\mathbf{1 3 2}}$

\section{Restoring Title VII's Broad Remedial Powers}

The imbalance between rights and remedies provided under title VII must be redressed by Congress. It is highly unlikely that courts will take this initiative, since they have summarily denied compensatory and punitive damages under title VII for approximately ten years. As this Note has argued, however, courts would be fulfilling, not violating, Congress' intent were they to provide such relief for intangible injuries.

Thus, Congress must amend title VII to provide explicitly for compensatory and punitive damages and restore the broad anti-discrimination powers originally envisioned. Now is the time for Congress to act. Not only has the full scope of the imbalance between rights and remedies under title VII only recently manifested itself, but the current political climate provides a golden opportunity for passing such an amendment. Indeed, in February, 1990, the Civil Rights Act of 1990 was introduced in both the House of Representatives and the Senate to restore and improve the protections against discrimination that have been eroded under a series of Supreme Court decisions issued in the summer of $1989 .{ }^{133}$ The bills would amend title VII to provide explicitly for compensatory and punitive damages. ${ }^{134}$ This section is critical for the Act to achieve its stated purpose of "strengthen[ing] existing protections and remedies available under Federal civil rights laws to provide more effective deterrence and adequate compensation for victims of discrimination." ${ }^{2135}$ As the Act gains momentum from the coalition galvanized by the recent detrimental Supreme Gourt decisions, Gongress should take advantage of this opportunity to strengthen title VII's remedial provisions.

132. This has only occurred recently since the Supreme Court did not recognize the hostile work environment cause of action until 1986. See Meritor Sav. Bank v. Vinson, 477 U.S. 57 (1986).

133. The bills, H.R. 4000, 101st Cong., 2d Sess. (1990); S. 2104, 101st Cong., 2d Sess. (1990), are identical and were introduced on February 7, 1990. The cases targeted include Patterson v. McLean Credit Union, 109 S. Ct. 2363 (1989), see supra notes 57-60 and accompanying text, and Wards Cove Packing Co. v. Atonio, 109 S. Ct. 2115 (1989) (increasing burden of proof on plaintiffs in title VII disparate impact cases).

134. H.R. 4000, supra note 133 , § 8; S. 2104, supra note 133, § 8. The House and Senate bills would both amend section 706(g) of title VII by adding the following identical language: "( $\mathrm{A})$ compensatory damages may be awarded; and (B) if the respondent . . . engaged in the unlawful employment practice with malice, or with reckless or callous indifference to the Federally protected rights of others, punitive damages may be awarded against such respondent . . . ."

135. H.R. 4000 , supra note $133, \S 2(\mathrm{~b})(2)$; S. 2104 , supra note $133, \S 2(\mathrm{~b})(2)$ (identical language). Significantly, the second of the two findings included in each bill's "Findings And Purposes" Section is that "existing protections and remedies under Federal law are not adequate to deter unlawful discrimination or to compensate victims of such discrimination." H.R. 4000, supra note 133, $\S 2(\mathrm{a})(2) ;$ S. 2104, supra note $133, \S 2(\mathrm{a})(2)$ (identical language). 
Congress should understand that such an amendment to title VII would actually restore the statute's broad remedial powers. As this Note has demonstrated, the courts, and not Congress, created the imbalance between rights and remedies under title VII by misinterpreting the statute's legislative history. Therefore, by invalidating the unduly narrow judicial construction of title VII's relief provisions, Congress would be reasserting its 1972 desire that title VII should provide all necessary relief to victims of employment discriminaton.

The two main stumbling blocks in the path of such reform are the fact that awarding damages would likely require a right to a jury trial under title VII, and the political barrier posed by the business community's opposition to increased costs. Neither of these obstacles is insurmountable. Awarding compensatory and punitive damages under title VII would probably trigger the right to a jury trial, ${ }^{136}$ since under the Seventh Amendment, actions for legal remedies, unlike purely equitable actions, require a jury trial. ${ }^{\mathbf{1 3 7}}$ However, the current enforcement mechanisms for employment discrimination claims can certainly accommodate jury trials. Jury trials are already available under two other employment discrimination statutes whose enforcement methods are similar to those under title VII: the Age Discrimination in Employment Act (ADEA) ${ }^{\mathbf{1 3 8}}$ and the Equal Pay Act. ${ }^{139}$ Some commentators have contended that jury trials would be impracticable under title VII since employment discrimination cases often involve complex and technical questions beyond a jury's competence, ${ }^{140}$ but there is no evidence that juries in ADEA and Equal Pay Act actions have encountered such difficulties. Similarly, experience under these statutes refutes the arguments that jury trials under title VII would cause intolerable delays or wrongfully circumvent the Act's administrative enforcement procedures. The EEOC administers the $\mathrm{ADEA}^{\mathbf{1 4 1}}$ and the

136. See, e.g., Curtis v. Loether, 415 U.S. 189 (1974) (holding that compensatory and punitive damages under Fair Housing Act are legal remedies requiring right to jury trial). A recent decision by one Federal district court held that jury trials are currently available under title VII and pointed out that the Supreme Court has never explicitly decided this issue. Beesley v. Hartford Fire Ins. Co., 723 F. Supp. 635 (N.D. Ala. 1989).

The authors of the Civil Rights Act of 1990 include in the section granting compensatory and punitive damages under title VII a provision for jury trials: "If compensatory or punitive damages are sought with respect to a claim arising under this title, any party may demand a trial by jury." H.R. 4000 , supra note $133, \S 8 ;$ S. 2104, supra note $133, \S 8$ (identical language).

137. Ser D. DobBs, supra note $34, \S 2.6$. The distinction between legal and equitable relief derives from the historic division between courts of law and courts of equity. See id. $\S 2.1$.

138. 29 U.S.C. $\$ \S 621-634$ (1982). The ADEA explicitly provides for jury trials. Id. $\S 626(\mathrm{c})(2)$. Jury trials are not available, however, in ADEA actions against the Federal Government. Lehman v. Nakshian, 453 U.S. 156, 168-69 (1981).

139. 29 U.S.C. $\$ 206$ (d) (1982). The Equal Pay Act is part of the Fair Labor Standards Act, 29 U.S.C. $\$ \$ 201-219$ (1982). It has been held to permit jury trials. See, e.g., Hodgin v. Jefferson, 447 F. Supp. 804, 809-10 (D. Md. 1978).

140. See, e.g., Developments, supra note 122, at 1264.

141. 29 U.S.C. $\S 626$ (c) (1982). 
Equal Pay Act ${ }^{142}$ in addition to title VII, and the procedures for processing charges under these three statutes are virtually identical. ${ }^{143}$

In addition, Congress should not permit the fact that awards of compensatory and punitive damages will impose additional costs on some businesses to block an amendment to title VII for at least two reasons. First, although punitive damages awards can be substantial, they would only be available when the employer's conduct was sufficiently egregious to meet specified standards. ${ }^{144}$ They should therefore be viewed by employers as a deterrent, and any employer who takes proper preventive measures should avoid punitive damages. Secondly, providing for compensatory and punitive damages under title VII is not a radical step. Rather, this would simply bring title VII into conformity with numerous other causes of action ranging from tort suits to section 1981, which already hold discriminators accountable for the consequences of their actions. Title VII was passed with this aim in mind, and it is time to restore the statute's broad remedial powers to achieve this goal.

\section{Conclusion}

The hostile work environment cause of action under title VII was premised on the realization that "today employment discrimination is a far more complex and pervasive phenomenon, as the nuances and subtleties of discriminatory employment practices are no longer confined to bread and butter issues."145 Under the current judicial interpretation of title VII, however, only "bread and butter" harms may be remedied. Whether the employee has suffered a discriminatory discharge or hostile environment harassment, no compensatory and punitive damages are available to redress her intangible injuries or to deter future discrimination.

As hostile work environment cases dramatically illustrate, title VII provides many discrimination victims a right without a remedy. The narrow judicial interpretation of title VII violates Congress' intent to grant broad relief to the victims of discrimination. As a result, Congress must now act to provide for compensatory and punitive damages and thereby restore title VII's broad remedial powers. As the Supreme Court has declared, "[w]e must . . . avoid interpretations of Title VII that deprive victims of discrimination of a remedy."148

142. Reorg. Plan No. 1 of 1978, 3 C.F.R. $\S 321$ (1978), reprinted in 5 U.S.C. app. at 1366 (1982).

143. B. Schlet \& P. Grossman, Employment Discrimination Law 938 n.51 (2d ed. 1983). Title VII, the ADEA, and the Equal Pay Act each provide a private right of action after exhaustion of administrative remedies. The trials are by jury under the ADEA and the Equal Pay Act, but are non-jury under title VII. See id. at 438-42, 487-95, 1058-59.

144. For example, the Givil Rights Act of 1990 would provide a statutory standard to determine when punitive damages are available. For the statutory language, see supra note 134.

145. Rogers v. EEOC, 454 F.2d 234, 238 (5th Cir. 1971), cert. denied, 406 U.S. 957 (1972).

146. County of Washington v. Gunther, 452 U.S. 161, 178 (1981). 